\title{
TRANSFERABILITY OF BANKRUPTCY ACTIONS: A PROCEDURAL ANOMALY
}

\section{S ection 2a(I) of the Bankruptcy Act authorizes each federal district}

court to adjudge bankrupt those persons, among others, who have their principal place of business, residence, or domicile within the court's territorial jurisdiction. ${ }^{1}$ Although this section has been regarded in some quarters as imposing a jurisdictional prerequisite, ${ }^{2}$ the extensive amendment, in 1952, of the transfer provisions of the Act, ${ }^{3}$ lends support to

${ }^{1} 30$ STAT. $545(1898)$, as amended, I I U.S.C. $\$$ I I (1952). More specifically, this section provides that courts of bankruptcy may "[a]djudge persons bankrupt who have their principal place of business, resided or had their domicile within their respective territorial jurisdictions for the preceding six months, or for a longer portion of the preceding six months than in any other jurisdiction, or who do not have their principal place of business, reside, or have their domicile within the United States, but have property within their jurisdictions, or who have been adjudged bankrupts by courts of competent jurisdiction without the United States, and have property within their jurisdictions, or in any cases transferred to them pursuant to this Act." See note 3 infra.

${ }^{2}$ In re Federman, II9 F.2d 754 (2d Cir. 1941); Higgins v. State Loan Co., I I4 F.2d 25 (D.C. Cir. 1940); In re Ettinger, 76 F.2d 741 (2d Cir. 1935); I Remington, BANKRUPTCY $\$ 40$ (sth ed. I950).

Prior to 1952, the effect of non-compliance with section $2 \mathrm{a}(\mathrm{x})$ was not altogether clear. On the one hand, a number of decisions seemed to regard compliance as necessary to give the court power over the subject matter. of the action,. and, absent some element of estoppel or laches, non-compliance could be raised as a basis for setting aside the adjudication at any time. In re Federman, supra; In re Ettinger, supra; Finn v. Carolina Portland Cement Co., 232 Fed. 815 (5th Cir. 1916); In re Enjay Holding Co., Inc., 18 F. Supp. 446 (S.D.N.Y. 1937); In re Garneau, 127 Fed. 677 (7th Cir. 1904). Other decisions seemed to assume that section $2 a(1)$ compliance was necessary only to give personal jurisdiction over the debtor and indicated that where the objector had taken part in the proceedings, he could not later contest the adjudication on grounds of non-compliance with section $2 \mathrm{a}(\mathrm{r})$. Fairbanks Shovel Co. v. Wills, 240 U.S. 642 (1916); In re Mason, 99 Fed. 256 (W.D.N.C. 1900). Still other decisions explicitly. referred to the requirements of that section as venue requirements. In re Evans, 85 F.2d 92 (2d Cir. 1936); In re Consolidated Burner Service Corp., 32 F. Supp. 835 (S.D.N.Y. 1940). With regard to dismissal, of course, it made no difference in most cases whether section $2 a$ ( 1 ) was regarded as a jurisdiction or a venue statute since a court could only transfer a case when actions had been filed in two different courts, each one satisfying a section $2 a(x)$ requirement.

${ }^{3} 66$ STAT. 424 , I I U.S.C. $\$ 55$ (1952). The pre-1952 transfer provisions, now contained in section $32(\mathrm{a})$, provide that "[i]n the event petitions are filed by or against the same person .... in different courts of bankruptcy each of which has jurisdiction, the cases shall, by order of the court first acquiring jurisdiction, be transferred to and consolidated in the court which can proceed with the same for the greatest convenience of the parties in interest." These provisions were amended, in 1952, by the addition of subsections (b) and (c). Subsection (b) provides for the transfer of any action, in which venue is improperly laid "to any other court of bankruptcy in which the action could have been brought." Subsection (c) authorizes the transfer of any case to any other court of bankruptcy" "regardless of the location of the principal assets of the 
the contention that section $2 a(I)$ is rather a venue provision. A recent district court decision ${ }^{5}$ has highlighted this divergency of attitude and has underlined the urgent need for definitive treatment of the true nature of this section as well as the proper application of the new transfer provisions, section $32(\mathrm{~b})$ and (c).

In In re Martinez, ${ }^{6}$ petitioners, proceeding under chapter XIII of the Bankruptcy Act, ${ }^{7}$ failed to allege any of the section $2 a$ (I) requirements, whereupon the referee dismissed the proceedings for want of

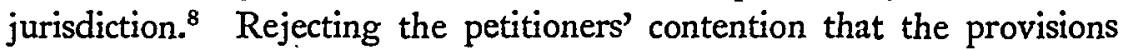
of section $2 a(I)$, in light of the 1952 amendments to section 32 , now relate merely to venue and, accordingly, may be waived, the district court, on appeal, affirmed. ${ }^{9}$

bankrupt, or his principal place of business, or his residence, if the interests of the parties will be best served by such transfer." See 2 Collier, BANkruptcy $\$ 32$ (14th ed. 1940, Supp. 1956); I ReMington, Bankruptcy \$51.5 (Supp. 1957).

As indicated by H.R. Rep. No. 2320, 82d Cong., 2d Sess. 7 (1952), these amendments were modeled after provisions similarly available in non-bankruptcy proceedings. "[Section $32(b)]$ incorporates the substance of the general statute on venue of district courts stated in [28 U.S.C. $\$ 1406]$, modified only to accommodate it to the Bankruptcy Act. ... [Section $32(\mathrm{c})$ ] makes available to the bankruptcy judge a power to transfer a case ... similar to that now accorded the judge in a non-bankruptcy proceeding by [28 U.S.C. $\left.\$ \mathrm{I}_{404}(\mathrm{a})\right]$. This power could already be exercised by a judge in a Chapter $X$ proceeding, because of the authority granted by section 118 . A cause is also added to section $2 \mathrm{a}(\mathrm{I})$ of the act ... to authorize the court to exercise jurisdiction in a case so transferred to it." See note I supra. See also, Comment, The Scope, Effect and Review of Orders Under $1404(a), 8$ STAN. L. REv. 388 (1956); Note, 18 N.Y.U.L.Q. REv. 399, 404-05 (1940).

* It should be observed that a few cases have already indicated that section $2 a$ (1) no longer relates to jurisdiction. For example, in Saper w. Long, 13 I F. Supp. 795, 796-97 (S.D.N.Y. 1955) the court concluded: "The very passage of section 32 of the Bankruptcy Act permitting a court to transfer cases to other districts was a recognition by Congress that [section $2 \mathrm{a}(\mathrm{I})$ ] . . related solely to venue." See also, In re Flexton Corp., 208 F.2d 869 (2d Cir. 1953); In re Fada Radio \& Elec. Corp., 132 F. Supp. 89 (S.D.N.Y. 1955); In re Marine Aircraft Corp., 118 F. Supp. 844 (S.D.N.Y. I 954). Cf. In re Consolidated Burner Service Corp., 32 F. Supp. 835 (S.D.N.Y. 1940); In re Evans, 85 F.2d 92 (2d Cir. 1936). But cf. In re Pilgrim Plumbing Supply Corp., 123 F. Supp. 823 (S.D.N.Y. 1953).

In re Martinez, 140 F. Supp. 221 (D. Kan. 1956).

I Ibid.

52 STat. 930 (1938), I I U.S.C. \$ 1001 (1952).

${ }^{8}$ Actually, there were two proceedings involving wage earners plans under Chapter XIII. Since neither petition indicated that venue had been properly laid, the referce issued an order requesting that an order be obtained from the court fixing venue. Upon failure of such an order to issue, the referee dismissed the proceedings.

- Arguably, the court's holding virtually nullified the effectiveness of section 32 (b) since this section is applicable only where venue has been laid in the wrong court. However, since none of the parties to the proceedings entered an objction to the improper venue, it is conceivable that the availability of transfer turns upon whether or not an objection to venie has been raised; and, that, absent such objection, dismissal rather than transfer must be ordered. To this effect, the court said: "But this is not to say that the 
The conclusion that a bankruptcy proceeding must be dismissed if none of the alternative requirements of section $2 a(I)$ have been satisfied is at least somewhat questionable. For, the underlying premise that section $2 a(\dot{I})$ is jurisdictional in nature is quite incompatible with the text of section 32(b), which provides:

Where vemue in any case filed under this title is laid in the worong court of bankruptcy, the judge may, in the interests of justice, upon timely and sufficient objection to venue being made, transfer the case to any other court of bankruptcy in which it could have been irought. (Emphasis added.) ${ }^{10}$

Initially, therefore, it would appear that section 32 (b) implicitly regards the provisions of section $2 \mathrm{a}(\mathrm{I})$ as going to venue rather than jurisdiction; otherwise there could be no wrong venue which the former section could be invoked to cure. ${ }^{11}$ Furthermore, the permissive language in which the authority to transfer is couched, as well as the prerequisite that "objection to venue" be made before such a transfer can be effected, implies a breadth of discretion in the court's disposition of objection based on non-compliance with section $2 \mathrm{a}(\mathrm{I})$ that is inconsistent with the finding that its provisions are jurisdiction. If satisfaction of one of the alternatve requirements of section $2 a(I)$ were necessary to empower the court to entertain a bankruptcy matter, its absence presumably would compel dismissal. ${ }^{12}$

Perhaps the most persuasive indication that section $2 a(I)$ was congressionally received as relating merely to venue is found in the legislative history of section 32 (b). Significantly, in reporting out the bill containing this latter section the House Report declared: "Ordinarily, no doubt, the venue rules in bankruptcy will serve the interests of justice, but in the event that in the special case they do not, the judge will have

'transfer' statute, as amended, is meaningless and will not be given full effect. . . Under sub. b, 'upon timely and sufficient objection to venue being made', cases will be transferred ... when the judge is convinced that such action will be in the interest of justice.' " (emphasis added). 140 F. Supp. at 225 .

${ }_{10} 30$ STAT. 544 (1898), as amended, 11 U.S.C. $\$ 55$ (1952).

11 "By enabling the Court to transfer to another district Congress impliedly recognized [section $2 a(\mathrm{I})]$ to be simply a venue statute. ... [T] his is clearly the intent of Congress reading [section $2 \mathrm{a}(\mathrm{I})]$ together with [section $32(\mathrm{~b})]$." Saper v. Long, I 3 I F. Supp. 795, 796-97 (S.D.N.Y. 1955). See note 4 supra.

- ${ }^{23}$ The Martines decision apparently stands for this proposition despite language to the contrary in its opinion. For the court stated that "in the view it now entertains, [it will not] assume jurisdiction generally over bankrupts ... not within its District and not within any of the categories set out in Section 2 of the Bankruptcy Act." $140 \mathrm{~F}$. Supp. at 225 . See note 2 supra. 
the discretion to retain the proceeding"13 (emphasis added.) Thus, the legislative history of section $32(\mathrm{~b})$ as well as the more reasonable construction of its text impels the conclusion that section $2 a(I)$ is a venue, not a jurisdictional, provision.

Assuming, then, that the provisions of section 2a(I) refer to venue, it is further clear that categorical dismissal of an otherwise meritorious petition for want of proper venue substantially frustrates congressional design. For, section $3^{2}$ (b) and (c) contemplates the theoretical availability to a court of three alternative modes of disposition of an improperly filed petition: retention and transfer, as well as dismissal. And in light of the broad powers that this section now makes available, the dismissal of such a petition would seem no longer to be a tenable course. For, the preservation of an early filing date of a petition in bankruptcy is of prime importance both for the purpose of utilizing alleged acts of bankruptcy as the bases for an involuntary adjudication, ${ }^{14}$ and for the purpose of dating the avoidance powers of the trustee in the event of an adjudication ${ }^{15}$ - and this can be effected only through the court's exercise of its powers to retain or transfer the matter..$^{10}$

If, then, a bankruptcy court is constrained either to retain or to transfer a meritorious petition, it is important to consider the factors that should determine this choice. Where no objection is made to venue in a court that does not meet the criteria of section $2 a(I)$, it would seem that the court should proceed with the case-as it would do in a non-bank-

\footnotetext{
${ }^{13}$ H. R. Rep. No. $2320,82 \mathrm{~d}$ Cong., 2d Sess. 7 (1952). See notes 3, 4 supra.

14 30 STAT. 546 (1898), as amended; i I U.S.C. \$2I (b) (1952).

15 30 STAT. 562 (1898), as amended, in U.S.C. $\$ 96 a(1)$, b (1925) (Preferential transfers), 30 STAT. 564 (1898), as amended, i 1 U.S.C. $\$ 107$ (a) (1592) (liens resulting from judicial proceedings); 30 STAT. 564 (1898), as amended, 11 .U.S.C. $\$ 107$ (d) (1952) (fraudulent conveyances).

${ }^{10}$ Factors which, in non-bankruptcy cases, have been similarly significant in decisions against dismissal for want of proper venue are: the possibility that the running of the statute of limitations'may bar the action in the forum finally deemed appropriate; the expense and delay involved in the commencement of a new action; and, the difficulty in re-obtaining jurisdiction. Orr v. United States, 174 F.2d 577 (2d Cir. 1949). See also, Internatio-Rotterdam, Inc. v. Thompson, 218 F.2d 514 (4th Cir. 1955); Untersinger v. United States, 18 × F.2d 953 (2d Cir. 1950); Norris v. Yates, 109 F. Supp. 436, 437 (W.D. Pa. 1953); Chicago \& N.W. Ry. v. Davenport, 95 F. Supp. 469, 471 (S.D. Iowa 195I). Cf. Norwood v. Kirkpatrick, 349 U.S. 29 (1955), 55 Colum. L. REv. 1067 (1955), 54 MICH. L. REv. 285 (1955), 41 CoRNell L. Q. 311 (1955); All State Freight v. Modarelli, 196 F.2d 1010, I011 (3rd Cir. 1952); Jiffy Lubricator Co. v. Stewart-Warner Corp., 177 F.2d 360, 362 (4th Cir. 1949). See generally, Keffee, Venue and Removal Jokers in the New Federal Judicial Code, 38 VA. L. REv. 569 (1952); Notes, 69 Harv. L. Rev. 119 (1955), 60 HARv. L. Rev. 424, 434 (1947). See text to note 13 supra.
} 
ruptcy matter..$^{17}$ Moreover, universal absence of objection would seem to justify the conclusion that this is, indeed, a proper court-one in which the retention of the matter is desirable.

Upon timely objection to venue, however, the court should guage its sufficiency and ascertain the court in which the proceedings can most conveniently and economically be heard. ${ }^{18}$ If it concludes that the case should be transferred, this procedure is clearly authorized by section 32 (b) if the court to which the transfer is proposed satisfies the criteria of section $2 a(I)$. However, the direction that transfer may run to a court in which the case "could have been brought" would seem to preclude transfer to another court which does not meet the criteria of section $2 a(r)$, although it may obviously be the most convenient forum. ${ }^{19}$

${ }^{27}$ Commenting upon the failure of a party to object to improper venue, Mr. Justice Van Devanter, speaking for the Court in Commercial Gas Ins. Co. v. Consolidated Stone Co., 278 U.S. 177, 179 (1929), opined: "[Venue] merely accords to the defendent a personal privilege respecting the ... place of suit, which he may assert, or may waive at his election."

${ }_{18}$ As a general rule, the most convenient forum should be determined by weighing considerations such as, "(1) proximity of creditors of every kind to the court; (2) proximity of the bankrupt to the court; (3) proximity to the court of the witnesses necessary to the administration of the estate; (4) location of the assets; and, (5) the economic and efficient administration of the estate." In re Triton Chemical Corp., 46 F. Supp. 326, 329 (D. Del. 1942). See also, Haas v. Gerstel, 134 F.2d 803, 804-05 (5th Cir. 1943); In re American Bond. \& Mortgage Co., 58 F.2d 379 (D. C. Maine 1932), aff'd, 65 F.2d 455 (Ist Cir: 1933), cert. denied, 290 U.S. 680 (1933); In re Devonian Mineral Spring Co., 272 Fed. 527, 532-33 (N.D. Ohio 1920); In re United Button Co., 137 Fed. 668, 672-73 (D. Del. 1904); In re Statewide Theatres Corp., 4 F. Supp. 86 (D. Del. I933). Moreover, that considerations of convenience and economy only should be decisive of the question as to which court should finally adjudicate the case seems clearly to be indicated by the language of section $32(\mathrm{c})$. For, in determining to which court transfer should run, the propriety of venue is to be disregarded, the order of transfer issuing to that court in which "the interests of the parties will best be served." See note 3 supra. For a discussion of the criteria which determine the most convenient forum in non-bankruptcy cases, see Kaufman, Observations on Transfer Under Section $2404(a)$ of the New Judicial Code, Io F.R.D. 595, 605 (1951).

${ }^{10}$ The conclusion that, under section $32(\mathrm{~b})$, transfer may issue only to a court which satisfies the venue requirements of section $2 a(r)$ seems to have its fundanental basis in the interpretation which non-bankruptcy courts, in the administration of transfer provisions similarly applicable, have given to the phrase "[could] have been brought." In this respect, it has generally been held that the court to which transfer is to be made be proper both as to venue and as to jurisdiction. Shapiro v. Bonanza Hotel, I 85 F.2d 777, 780 (9th Cir. 1950); Foster-Milburn Co. v. Knight, i8 I F.2d 949 (2d Cir. 1950). But see, Otto v. Hirl, 89 F. Supp. 72 (S.D. Iowa 1950). Apparently, the primary consideration in these decisions is the fear that the transfer provisions could in effect amount to a device for extra-territorial service of process. Accordingly, "[could] have been brought" has been construed to mean the practical probability, rather than the theoretical possibility, that the party resisting transfer would have been subject to service of process in the proposed transferee district. Masterpiece Productions v. United Artists, 90 F. Supp. 750 (E.D. Pa. 1950).

It might be argued, however, that this restrictive interpretation given to the transfer 
Thus, to localize a case in its most convenient forum in this situation, a subsequent transfer would be indicated under section $32(\mathrm{c})$, which empowers a court to transfer any case "regardless" of the propriety of venue "if the interests of the parties will be best served by such transfer."20 Such circuity; obviously not contemplated by the amendments, may be easily averted, however, by permitting the court in which the petition was originally filed, albeit not satisfying the criteria of section $2 a(I)$, to retain the matter or to transfer it to other courts not sanctioned by section $2 a(I)$ under the broader provisions of section $32(\mathrm{c})$, as the interests of the parties, would seem to dictate.

In final analysis, it seems clear that dismissal of a petition, whether on jurisdictional grounds, as in the Martinez case, or, for want of proper venue, contravenes the spirit of section 32 (b) and (c). Moreover, it gives rise to the anomalous possible situation that a convenient forum, owing to non-compliance with section $2 a(\mathrm{I})$, will be forced to transfer a case to a less convenient forum under section 32 (b) only to have it transferred back under section $32(\mathrm{c})$. It seems clear that the transfer provisions of section 32 were not intended to create such an anomaly. They were rather enacted to bring flexibility into the proceedings by permitting a court, in the exercise of its discretion, to transfer the case regardless of venue requirements; or, to retain the proceedings if the interests of justice and the convenience of the parties would thereby be best served.

provisions by non-bankruptcy courts should not be decisive in bankruptcy actions. First, the Federal Constitution would not prohibit the invocation of extra-territorial service of process in bankruptcy proceedings. Mississippi Publishing Corp. v. Murphree, 326 U.S. 438,442 (1946). And, although such nationwide service of process has been held only to apply to reorgarization proceedings under the Bankruptcy Act, Continental Bank v. Rock Island $R y_{\text {., }} 294$ U.S. 648, 683-84 (1935), the Suprene Court has intimated that, in this respect, there is no practical distinction between straight bankruptcy proceedings and reorganization. Ex parte Baldwin, 291 U.S. 610, 615 (1934). Secondly, it is conceivable that those hardships which may attend the use of extra-territorial service of process would not be present in the administration of sections $32(\mathrm{~b})$ and (c) since the choice of transferee forums is limited to those in which a case could be adjudicated in the "interest of justice" or in the "interests of the parties." In re Fada Radio \& Elec. Corp., Inc., 132 F. Supp. 89, 90 (S.D.N.Y. 1955). Cf. In re American Fuel \& Power Co. 3232 F. Supp. 107 (D. Del. 1940).

30 See note 3 supra. 